DECLASSIFIED

\title{
CHEMICAL PROCESSING DEPARTMENT MONTHLY REPORT SEPTEMBER 1964
}

\author{
OCTOBER 21. 1964
}

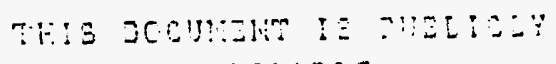

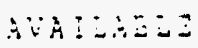

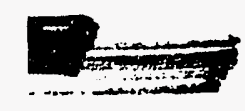

HANFORD ATOMIC PRODUCTS OPERATION RICHLAND, WASHINGTON

GENERAL ELECTRIC

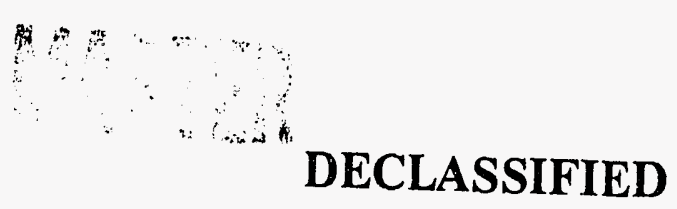




\section{LEGAL NOTICE}

This report was prepared as an account of Government sponsored work. Neither the United States, nor the Commission, nor any person acting on behalf of the Commission:

A. Makes any warranty or representation, expressed or implied, with respect to the accuracy, completeness, or usefulness of the information contained in this report, or that the use of any information, apparatus, method, or process disclosed in this report may not infringe privately owned rights; or

B. Assumes any liabilities with respect to the use of, or for damages resulting from the use of any information, apparatus, method, or process disclosed in this report.

As used in the above, "person acting on behalf of the Commission" includes any employee or contractor of the Commission, or employee of such contractor, to the extent that such employee or contractor of the Commission, or employee of such contractor prepares, disseminates, or provides access to, any information pursuant to his employment or contract with the Commission, or his employment with such contractor. 


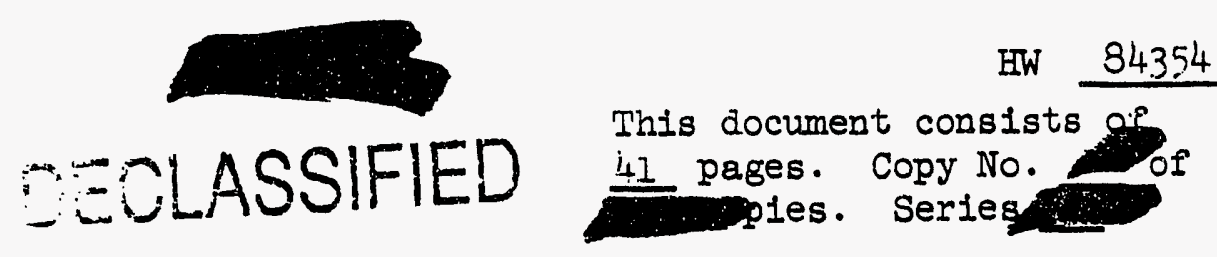

CHEMUT.CAI PROCESSING DEPARTMENTI

MONTHLY REPORT

$\underline{F O R}$

Cisssifieation Gancalled (Ghangs to

SEPTEMRTR, 1964

Complled By

Byauthority of $(9-P R-24$
Oebent 121 OPERATION MANAGERS

b.

P.m Elak $9-17-i 2$

RICHTAND, WASHINGTON

Work performed under Contract No. 4T $(4,5-1)-135 \%$ between

the Atomic Energy Commission and General Electric Company.

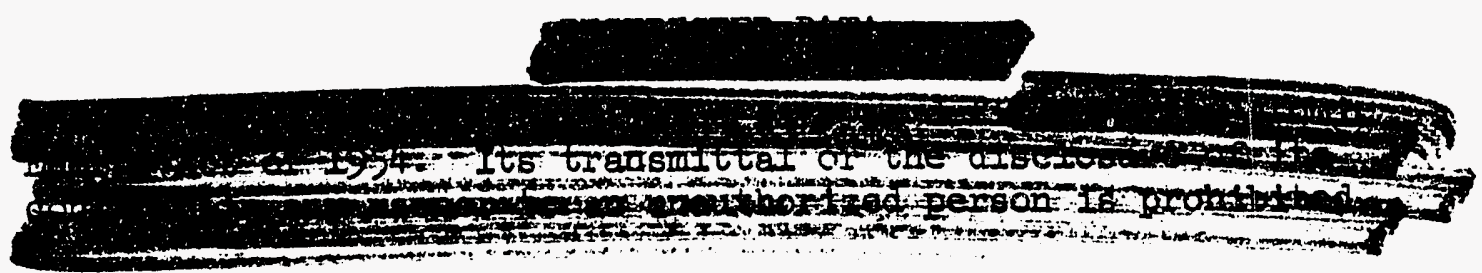

\begin{tabular}{l|l|l|l|l}
\hline Route To: & P.R. No. & Location & $\begin{array}{c}\text { Files } \\
\text { Route Date }\end{array}$ & Signature and Date \\
\hline & & & & \\
\hline & & & & \\
\hline & & & & \\
\hline & & & & \\
\hline & & & & \\
\hline
\end{tabular}


DISTRIBUTION

Copy Mumber

\begin{tabular}{|c|c|}
\hline & \\
\hline 1 & W. E. Johnson \\
\hline 2 & H. M. Parker \\
\hline 3 & R. A. Connell \\
\hline & M. K. Harmon \\
\hline 5 & W. M. Harty \\
\hline & W. J. Gartin \\
\hline & S. G. Smolen \\
\hline 9 & $\begin{array}{l}\text { R. E. IOmLinson } \\
\text { C. R. Bergdahl }\end{array}$ \\
\hline 1 & $\begin{array}{l}\text { General Electric Company, Palo Alto, California } \\
\text { Attention: F. E. Crever, Manager } \\
\text { Technical and Business Planning Operations }\end{array}$ \\
\hline 13 & $\begin{array}{l}\text { Atomic Energy Commission, Richland Operations office } \\
\text { Attention: J. E. Travis, Manager }\end{array}$ \\
\hline 16 & $\begin{array}{l}\text { Atomic Energy Commission, Washington 25, D. C. } \\
\text { Attention: F. P. Baranowski, Director } \\
\text { Production Division }\end{array}$ \\
\hline & $\begin{array}{l}\text { Extra } \\
300 \text { Files } \\
\text { Record Files }\end{array}$ \\
\hline
\end{tabular}




\section{SEULASSIFED}

TABLE OF CONTENTS

Distribution

Takle of Contents

Staff

I. Summary

II. Achievements

A. Produstion Operation

A-1 Throiger $4-3$

B. Purex Operation

B-1 wough B-y

C. Redox Operation

C.1 Throgh $6-3$

D. Weapons Manufactiring Operatice

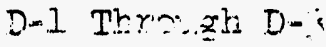

E. Firaccial Operation

E-I. Througt E-

F. Facilities Englnearirg Operation

Ful Thaz: F-6

G. Researoh and Engineering operation

$G-1$ Through $G-6$

III. Personrel Aotivities

T-I Through itust

IV. Safet:y and Sezurity

$x-1$

V. Reports Issied

L-I Tnrough i-s

VI. Patent Summary

$M=1$ 
General Manager, Atomic Products Division

General Manager, Hanford Atomic Products Operation

General Manager, Chemical Processing Department

Acting Manager, Production

Manager, Purex

Manager, Redox

Manager, Weapons Manufacturing

Manager, Finance

Manager, Research and Engineering

Manager, Facilities Engineering

Manager, Employee Relations
J. F. Young

W. E. Johnson

J. H. Warren

M. K. Harmon

W. M. Herty

S. G. Smolen

W. J. Gartin

R. A. Connell

W. S. Frank

H. P. Shaw

G. H. Sahler 


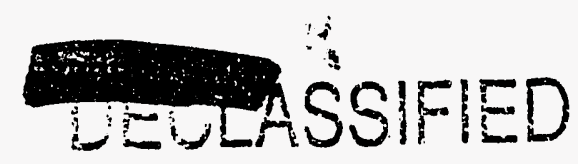

HW-84354

$\frac{\text { CHRMICAL PROCESSING DEPARTMENT }}{\text { MONTHLY REPORT }}$

SEPTEMMBER, 1964

\section{SUMMARY}

September production, as compared with the HAPO Production Forecast (HW-83319), is summarized below:

\begin{tabular}{|c|c|c|}
\hline & September & $\begin{array}{l}\text { Fiscal Year } \\
\text { To Date }\end{array}$ \\
\hline Separated plutonium nitrate & 110 & 113 \\
\hline Separated uranium nitrate & 108 & 111 \\
\hline Uranium oxide & 110 & 105 \\
\hline Plutonium metal buttons & 105 & 114 \\
\hline Fabricated parts & 101 & 89 \\
\hline
\end{tabular}

For the second consecutive month, exeellent production of all products was achieved. Redox performance was particularly good and output exceeded the previous record high for E-metal by 18.7 tons. The production of separated plutonium nitrate was also noteworthy, with output exceeding the record high established in June 1963 by $6.4 \mathrm{~kg}$.

The Purex canyon ventilation filter continued to be a problem during September. Adequate air flow was maintained by flexing the filter more frequently but the fiberglass bed continued to recompress.

The HAPO I-B-I Cask, loaded in August with approximately 350,000 curies of strontium-90, was released for shipment on September 1.1. Loading of four STT casks with cesium 137 was also completed but shipment was delayed seven days until september 25 because of a pendirg railroad strike.

Approximately 400,000 curies of crude promethium-147 were recovered from suppernatant from the 106-A Waste Tank.

Sustained operation on the modiried acid-deficient precysle flowsheet, adopted during July, 1964 , was successfully demonstrated at Redox during september. With the extraction batteries operating at rear optimum rates for 676 holirs, E-metal production reached a new record high of 233.5 tons. It was also evident that the fllowsheet and the 
new IA precycle column were primarily responsible for better quality solvent, a factor of four reduction in corrosion rate in the backcycle concentrator, and twice the production capability between column flushes.

The processing of unclassified plutonium oxide was started for the Euratom program on september 24. Approximately half of the $175 \mathrm{~kg}$ order was completed by month-end.
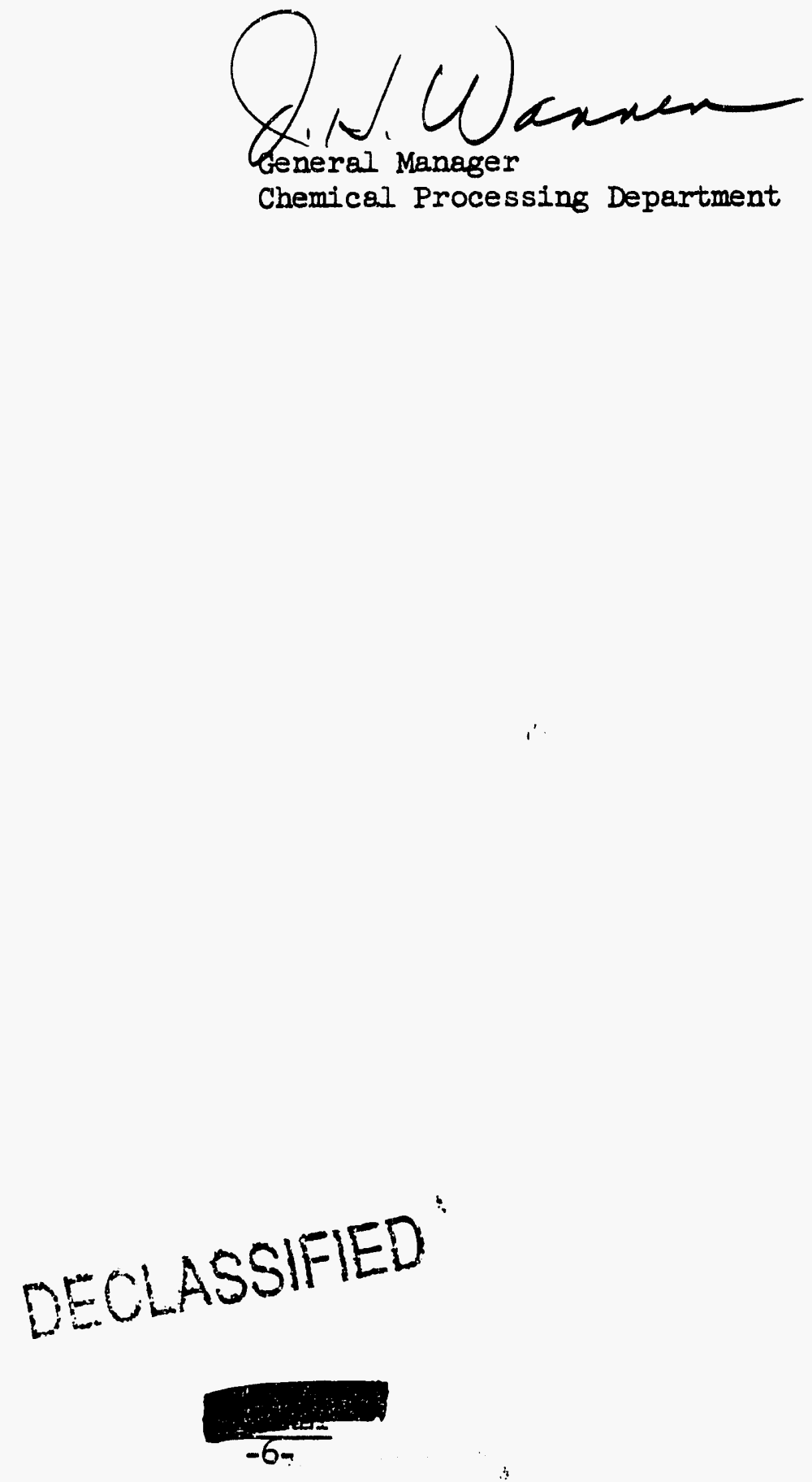


\section{$\Longrightarrow$ ECLASSIFIED}

CHEMICAL PROCESSING DEPARTMENT

MONTRLY REPORT

SEPTEMBERR 1964

II. ACHIEVEMENISS

A. PRODUCTION OPERATION

1. Production Statistics

a. Percent of Forecast (1) Achieved

September

Fiscal Year

Separated plutonium nitrate

Separated uranium nitrate

110

108

Uranium Oxide

110

Plutonium metal buttons

105

Fabricated parts

101

to Date

b. Purex

September

113

111

105

114

89

Urantum nitrate produced (tons)

Average production rate during operation (T/D)

Total waste loss (\%)

PIutonium

Uranium

On-line efficiency ( $\%$ )

508

23

August

856

30

$\begin{array}{cc}0.45 & 0.28 \\ 0.25 & 0.22 \\ 92 & 99\end{array}$

c. Redox

Uranium nitrate produced (tons)

Average production rate during operation (T/D)

233

Total waste loss ( $\%$ )

Plutonium

Uranium

On-Iine efficiency (\%)

0.21

94

55
5

d. Uranium Reduction (tons)

Normal $\mathrm{UO}_{3}$ loaded

Enriched $\mathrm{JO}_{3}$ loaded

Normal $\mathrm{UO}_{3}$ approved for storage

721

152

721

152

Enrlched $\mathrm{UO}_{3}$ approved for shipment

0

152

Enriched $\mathrm{UO}_{3}$ shipped

304

219

676

102

676

102

0

50

Normal UNH backlog

331

Enrlched UNH backlog

232

(1) HW-83319, HAPO PRODUCTION FORECAST. 
e. Plutonlum Metal Processing

Reduction yleld (\%)

Product recovery output (Kgs)

Product recovery backlog (Kgs)

Waste disposal (grams)

1. Power

Raw water pumped (gpm)

Filtered water pumped (gpm)

Maximum steam generated (Ibs./hr.)

Average steam generated (Ibs./hr.)

Total steam generated (M Ibs.o)

coal consumed (tons)
September August

$\begin{array}{rr}97 & 97 \\ 239 & 83 \\ 280 & 1380 \\ 719 & 746\end{array}$

200-West 200-Eest.

$6001 \quad 12128$

$1210 \quad 1111$

$110000 \quad 205000$

$91000 \quad 170000$

$65411 \quad 122471$

$3242 \quad 6208$

For the second consecutive morth, excellent production of all products was achieved. Redox performance was particularly good and output exceeded the previous record high for E-metal by 18.7 tons. The production of separated plutonium nitrate was also noteworthy, with output exceeding the record high established in June 1963 by $6.4 \mathrm{~kg}$.

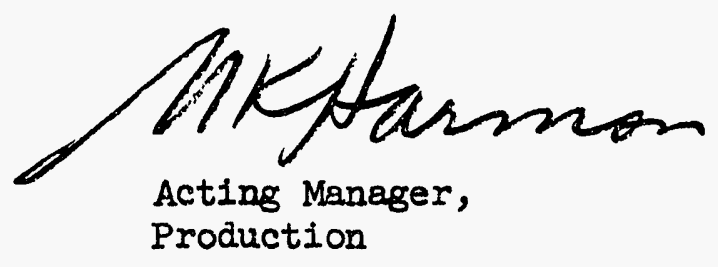

DECLASSIFIED

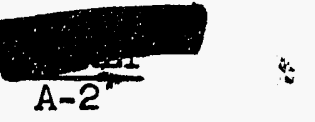


帒

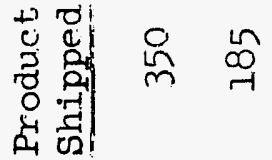

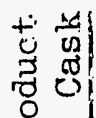

है म्ञा

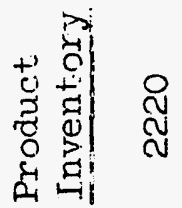

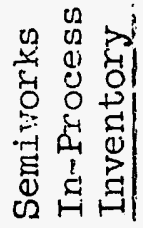

윰

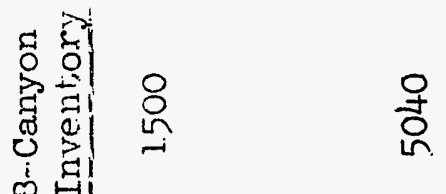

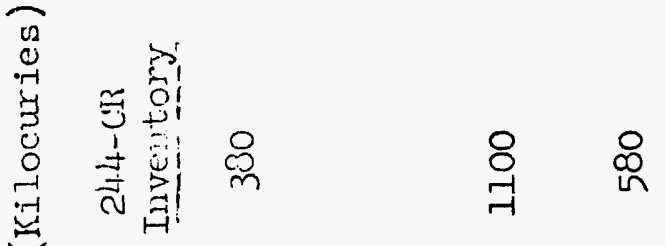

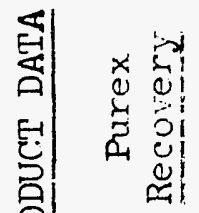

$c$

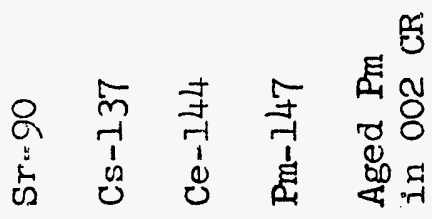

TE:T $18-\mathrm{MH}$

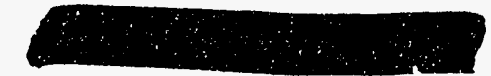

0IISS 47030 
CHEMICAI PROCESSING DEPARTMENT

MONTHLY REPORT

SEPPTEMBER, 1964

\section{ACHIEVEMENIS (Continued)}

\section{B. PUREXX OPERATION}

\section{Uperating Continuity}

Purex processing continued at a 3.6 capacity factor on regular metal until September 5, 1964 when rates were reduced to 3.0 to regenerate the "A" dissolver silver reactor. Unclassified metal was processed from September 9, 2964 antiI Ssptember 26, 1964 at a 2.8 capacity factor. A brief shutdown was taken to replace the HA column feed pump and control valve jumper on September 8, 1964. Another shutdown was taken September 26 and 27.1964 to complete an Ss Nuclear Material inventory and replace the $2 A$ column (firial. plutonium cycle) interface jumper. Regular metal processing resumed on september 28, 1964 and rates were increased to a 3.6 carycity factor.

Neptunium purificaticn mu 20 \%: hipped on September 28, 1964 and mun 21 was completed.

Elght promethium-14? reccvery runs were completed at the Purex Head Bnd during the month. Approximately 72.000 gallons of Tank 106-A supernatant were processed, yielding about 400 kilocuries of crude promethium.

The Technetium STT cask, loaded concurrently with the Cesium STTs, was moved to the Strontium Semi"rorks for elution of the technetium. Continuous sugar denitration of the $6 \mathrm{M}$ nitric acid elutant was demonstrated at the strontium semiwork for the first time resulting in a twenty fivewfold volume reduction. No unusual problems were encountered. The technetium in the product solution was reloaded onto a small (50 liter) resin column for fission product decontamination and then eluted into 55 galion stainless steel drums for shipment to Separations Chemistry, Research and Engineering Operation.

B-Plant activity was limitod this month to routine inventory survelliance.

2. Processing Operation

Purex uranium and plutonium met specifications except for one week when uranium batches exceeded specifications and required blending. Two plutonium batches exceeded specifications.

Calorimeter checks on the HAFO I-B-I cask indicated a load of approximately 350 kilocuries of struntium 90 . The cask was released to the

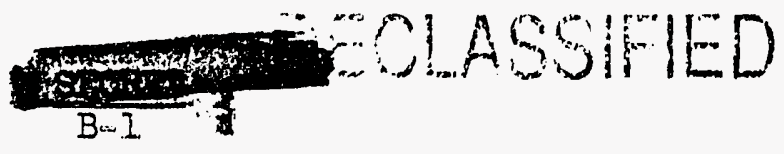




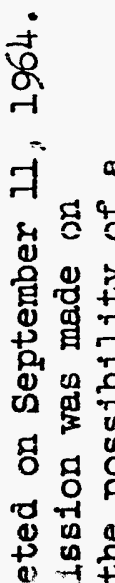

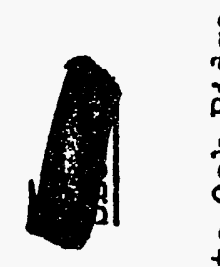

夏寒

व

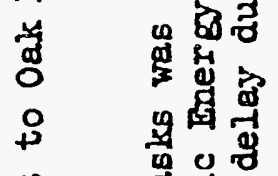

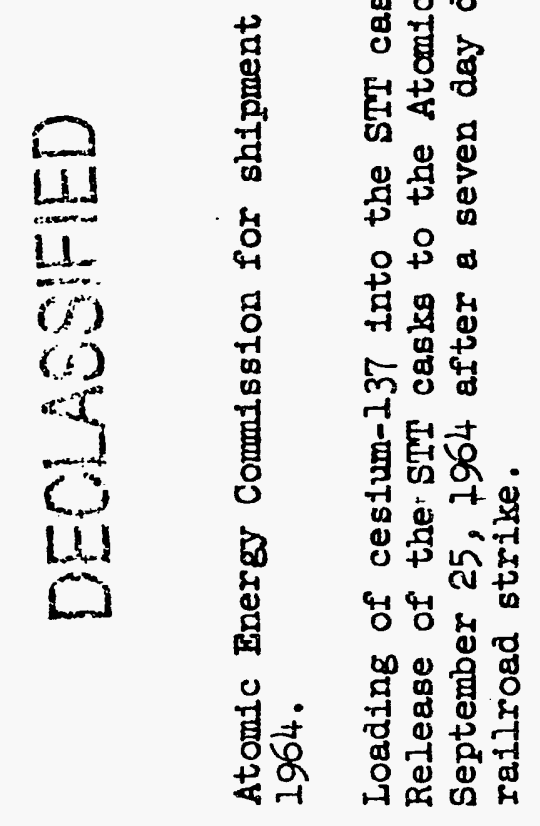

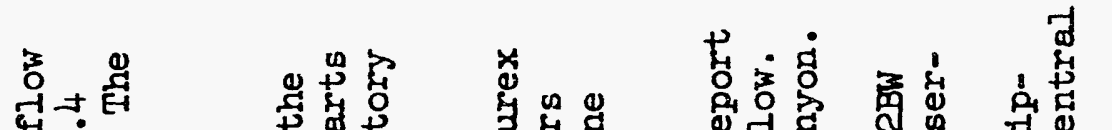
空

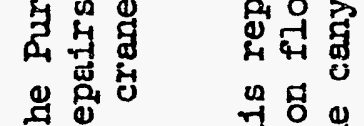
品

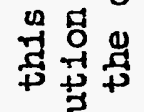

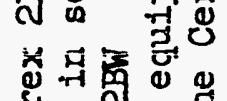
㟧 잉 突

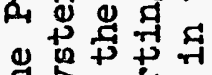

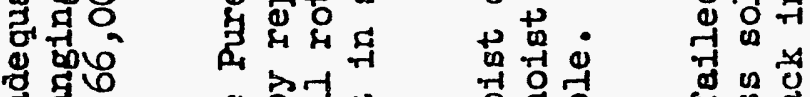
政 †

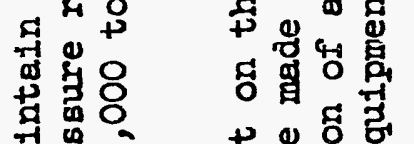

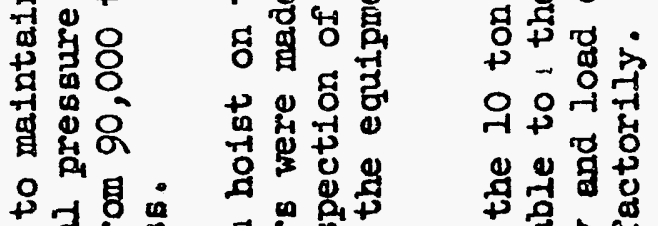

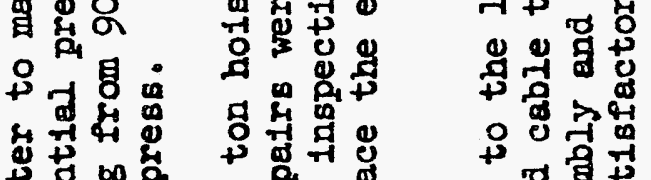

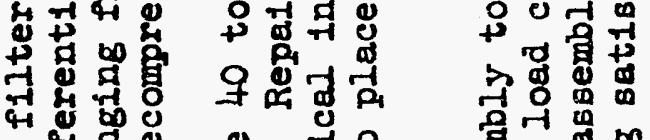

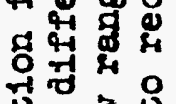

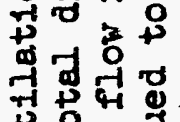

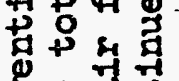

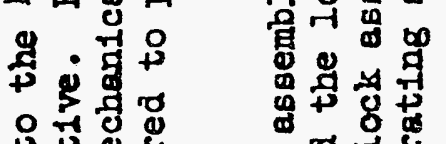

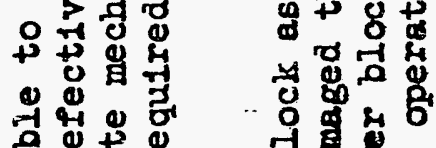
of

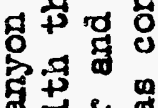

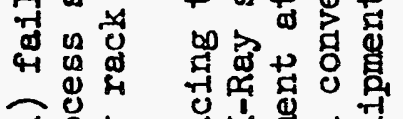

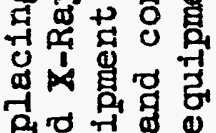
o 造 겅혀 ने ฆ

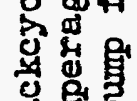
造息 O응 南主 年

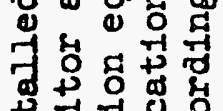

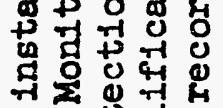
0 g 형

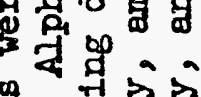
量要势

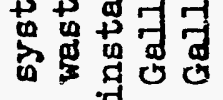

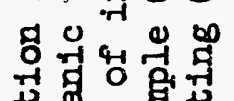
Fit

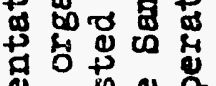
결 के

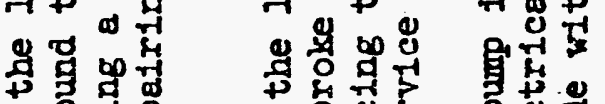
g월

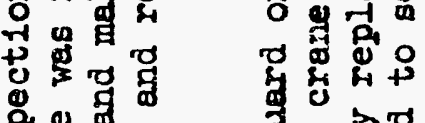
的要 g. 8

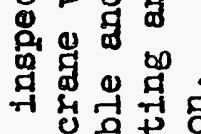

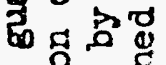

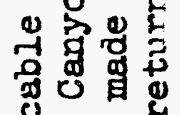

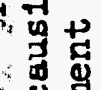

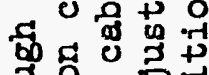

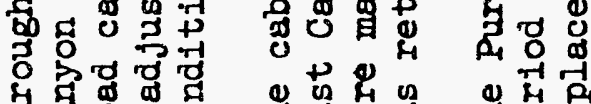

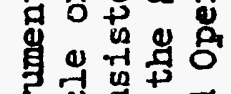
든

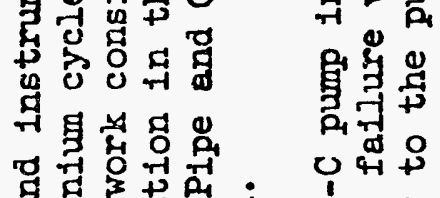

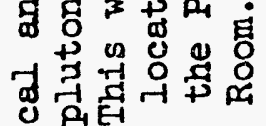

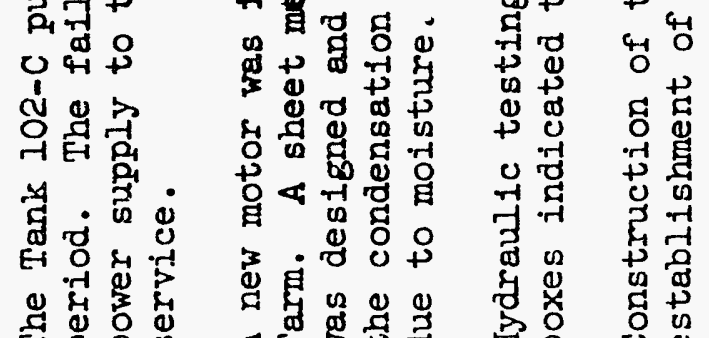

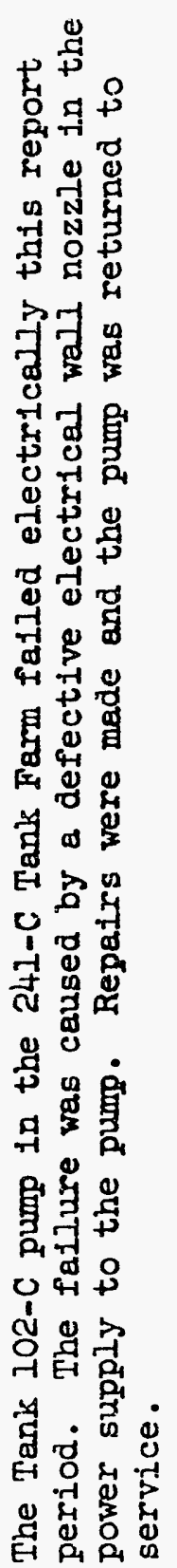


索 s 尌 。 舆 잉 告造 热运 दै 崩 †̃ ‡.

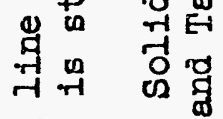

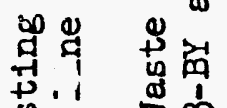
讨 \&

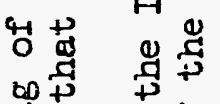

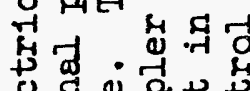

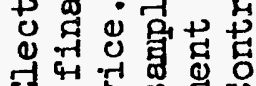
ํㅜㄹ

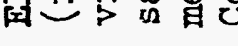

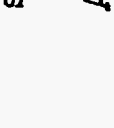


B-Cell maintenance work at the Strontulu Serniworks c intinued with the replacement of the HC column product vilve and the HA column alternate waste valve, the removal of the HA column product, IC column waste. and HC column product ion chambers for repair, and the installation of the HA column scrub section differential pressure cell. The Tank 81 process olution pump in B-Cell was also repaired during the month.

4. Radiation Experience

The addition of eleven tons of Bentcnite to the Gable Mountain Swamp was completed during september. Back-filling of the shore line of the swamp was undertaken to provide better confinement of water in the swamp. The vater level in the swamp ws shown sufficient increase during the month to preclude the need for further Bentonite addition in the near futrure. Radiation readings at the shcre line are no longer a problem.

Iodine emission was normel except for the seven day period ending october 1, 1964 during which 2.28 curies were emit,ted. Mereuric nitrate has been added to the dissolved feed to suppress the emission rate.

5. Analytical

Installation of the wide-beta proportional counter was completed during September. Calibration and background checks are in progrsss. This counting instrument will provide the means to obtain greater socuracy and precision on analyses for the beta emitting fission product isotopes. otiner potential uses, including the automation of repetitive counts for Irradiation Processing Department samples, are being investigated.

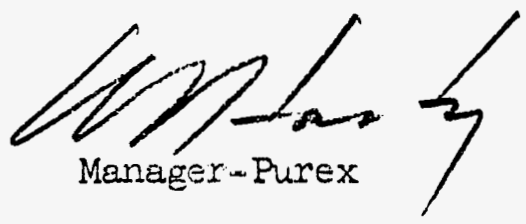

WM Harty :MLM:de

\section{DECLASSFIED}


CHEMICAL PROCESS NVG DEPARTYMUII

MONTHLY REPCR

SEPTENBER 1064

\section{ACHIEVEMENTS (Continued)}

\section{REDOX OFERAIIION}

1. Operatiad Continufty

The Rei ux plant operated exesptioraliy well throughout the montin and a new E-metal monthly production renod wis achieved. The preysous record of 214.8 tons, establisined duolng vanury 2963 , was exseeded by approximately $;$ pesent.

The Uranium Oxide plant operated satzastactorily throughout the month and the production of boti depieted and enriched uraxidr oxide exceeded that expected.

\section{Processing Operations}

\section{Q. Redox Processing}

E-metal processing was cont nicis thrciginout the month except for two short shutaown pexicds sotaling approxinateiy 36 hours for: 1) nitric acid elush ing of the IA precycle extraction column to correct flcoding conditions; 2) replaceinent of the $\mathrm{H}-4$ metal soiution oxidizer stean ccil wich falied on 9-22-64.

Sustained operation on the modified acla-defiolent precycle flowsheet, adoptod during Juil 2964 , was sucessfuliy demonstrated this montin. The extraction batteries were operated at near cptimum rates for 675 hours, or 96.8 percent of the time avaliable.

Improved operating effliciency, partisularly with respect to operatine continuity, produced waste iosses measized at 0.21 and 0.30 percent for urandur and plutonium, respectively. Fortyfour tons of uranfum, held in lag stcrage because of excessive ruthenium, were blended into sperisicatica with the currently produced material.

b. Uranium Oxide Processing

Processing operations were satisfactory throughout the month. Total downtime for equipment repairs was 44 hours, 24 of which were taken to complete preventive maintenance jobs.

One car of enriched $\mathrm{JO}_{3}$ powder exceeded the scdium specification ( 55 vo $50 \mathrm{ppm}$ ) but was shipped on a waiver ot specification from the customer. The Nat:onal Lead Company has been requested to re-analyze the material.

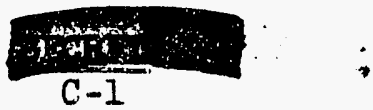




\section{Maintenance Experience}

a. Redox Plaxt

The Redox processing equipinent operated exceptionally well during the month and the mechsnical efficieney for time period was 97 percent.

A restriction in the waste lire from the $1 \mathrm{~A}$ precycle column to the D-It backcysle waste concentrator was encountered at August month-end, which reduced throughput rates to approximately 60 percent of nominal. A new IAW let-down jumper was fabricated and installed, which permitted rates to be increased to an average production throughput of 8.3 tons per operating day.

The steam coll in the $\mathrm{H}-4$ metal solution oxidation tank falled on 9-22-64 and 1.5 hours of downtime was taken to install. a new unit. Subsequent operation has been satisfactory.

Irternal painting of the high pressure inert gas recelving tank was completed this month and the tank returned to service without' incident.

b. Uranium Oxide Plant.

The ring gear and sprocket on the $X-30$ calciner feed tank agitator failed on 9-10-64. Since replacement parts were not readily available, an air sparger was installed pending arrival of ordered replacement equipment. Operation to date has been satisfactory.

The EDD-2 concentrator ( 100 percent UNH) was shut down this month for a general overbaul due to the erratic operation being experienced with the unit. Restrictions found in the recirculatior, off-gas, and eyclone drain-lines were removed and a new trap was installed on the coll outlet. Operation of the unit has improved; however, vacuum limitetions still restrict capacity and efforts to resolve the problem are continuing.

\section{Waste Hariding and Decortamination}

Equipment valued at approximately $\$ 85,000$ was recelved frow customers for decontamination, repair, inspection or burial during the month. Equipment valued at approximetely $\$ 35,000$ was returned to customers, representing a. savings of approximateiy $\$ 30,000$ based on the cost of new equipment.

\section{Radiation Experience}

The radioactivity detrectad in two of the hor zontal laterals beneath the 108-SX waste storage tank during August, increased from 150,000 $\mathrm{c} / \mathrm{m}$ to $260,000 \mathrm{c} / \mathrm{m}$ during september. However, there has been no change in the readings detected in vertical test weil No. 29 ana liquid level measurements indicate no loss of material. Checking of all waste transfer lines in the vicinity of both the 10 ? and the 
Q CLASSIFIED

108-sX tanks is confining and close survellianse will be kept to detect any changing trends.

6. Analytical Experience

The Redon Analytical Laboratory provided: 1) Thorium analyses to provide solvent extraction ratio data, and thorium oxide-nitric acid dissolution rates for the Materials and Process Chemistry Laboratory, Hl: 2) analyses for dissolved uranium and plutonium content to provide information for the evaluation of a reactor decontamination study for the Coolant Systems Development Operation, HI: 3) Iron, zinc, yttrium, neodymium, cerium and samarium determinations by $X$-ray spectrometer to provide performance data for the final "cold" run in the Separations Chemistry Laboratory promethium recovery facility; 4) low level uranium analyses in the presence of gross quantities of thorium to evaluate methods for the separation of uranium and thorium; 5) samarium-153 analysis of ceramic "SCRAM" balls which were exposed in the N-reactor.

A Anole Manager - Redo

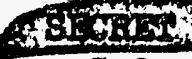

$\mathrm{C}-3$ 
CHEMICAL PEOCESSING DEPARTMENT MONTHLY REPORT

SEPTEMBER, 1964

\section{ACHIEVEMEIVTS (Continued)}

\section{WEAPONS MANUFACTURING OPERATION}

\section{Operating Continuity}

The fabrication of Model 1807 components and Model $74 \mathrm{w}$ components was without significant interruption during the month. The production of unfabricated plutonium was intermpted at mid-month in order to process plutonium oxide for the Euratom program. This special processing continued through the end of the month. Operation of the reclamation facility was without significant interruption, except for the performance of the slag and crucible dissolver where solids accumum lation continues to prevent normal operation. The miscellaneous treatment dissolvers and the laboratory-type dissolvers operated without interruption. The incinerator was started up following overhaul and operated at normal rates from mid.wonth.

\section{Processing Operations}

\section{a. Plutonium Fabrication}

Information on plutonium fabrication activities is presented in Document HW..84399 (Atomic Weapon Data).

\section{b. Plutonium Reduction}

Weapons-grade plutonium was processed to metal in the button line until mid-month. Unclassified metal production was then initiated and continued for several days Following this, work was started on the preparation of approximately 200 kilograms of unclassified plutonıum oxide to fill an order of 175 kilograms for the Ehratom frogram. Production of the oxide was approximately 50 per cent complete at monthwend. Calcium impurities were up to $200 \mathrm{ppm}$ and sodium impurities were up to $500 \mathrm{ppm}$. The final Euratom contract wili have to be drawn to allow this impurity level if this oxide is to be used for the order.

\section{c. Plutonium Feciamation}

Two hundred forty-one (241) kilograms of plutonium were delivered from the recovery facilities to the button line. Seventy-one (7I) kilograms of this came directly from the laboratory-type (glass) oxide dissolvers. 


\section{c. Plutonium Reclamation (Continued)}

Thirty-seven (37) waste boxes and six packages of leachables were processed in the incinerator during the time it operated during the month.

In the waste treatment and americium recovery facilities, 7.6 grams of americium were separated and loaded into an RC can for storage. Americium concentration was about one-half gram per liter.

Operation of the slag and crucible dissolver continued to be curtailed by solids accumulations and was further complicated by the failure of the Teflon liner. Repairs were made and limited operation was resumed at month-end.

The extraction of the plutonium from the waste stream has been satisfactory in the new waste treatment facility but recovery of the plutonium from the extractant is inadequate. The flow sheet is being modified to correct this problem.

3. Mechanical Performance

Performance of equipment in fabrication, inspection, and the button line was satisfactory during September. No unusual repairs were required.

The slag and crucible dissolver (TK-06) in the reclamation facility continued to require excessive attention. In addition to the accumulation of solids, the Teflon liner of the tee section bulged and prevented the scrap containers from being properly immersed in the solution. The faulty section was replaced by one from the other dissolver (TK-04) which is being modified in the 300 Area shops. Five Chempump failures were experienced in the reclamation facility.

The inadequate flow rate of the CAW aqueous waste to the waste treatment facility was corrected by the addition of a pump in the delivery line.

The installation of the 24-C Hood (Gorton lathe hood from the "C" fabrication line) on the "A" fabrication line is 75 per cent complete.

The installation of the hood for the highutemperature calcination, milling and sampling of the Euratom oxide is 95 per cent complete.

Repairs to the emission spectrograph were accomplished following resolution of an optical alignment problem by the manufacturer's representative.

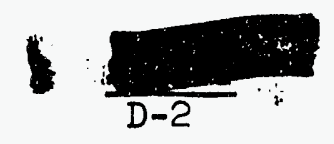


4. Radiation Experience

Fadiation and contamination control statistics for September revealed satisfactory performance

There were no cases of potential plutonium deposition.

5. Analytical Experience

$$
\begin{array}{lr}
\text { Number of Sampi }=s \text { Received } & 3,239 \\
\text { Number of Determinations } & 19,277
\end{array}
$$

A heavy analytical load resulted from high recovery activity and the outage of the emission spectrograph. These problems and the termination of several Chemical Analysts resulted in a high overtime level in the analytical unit.

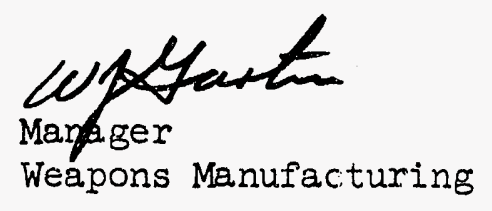

WJ Gartin:csj

\section{DECLASSIFIED}




\section{UELLASSIFIED \\ CHERIICAI PROCESS ING DEPARTMENT \\ MONTHLY REPORT \\ SEPTIIVIBER 196:}

\section{ACHIETHMINISS (Continued)}

\section{E. FINANICIAL OPEZATION}

\section{Production Cost Azsourting}

Call letters fol manpotrer and planned maintenance for the FY 1065 Nidyear Budget Review vere issued, with instructions that planning should be oriented towards remaining within currently available funàs.

Funaing problems are indicated in 02 and 03 Production, Isotope Inventory and 02 RC:D.

Initial reporting or the Weapons Standard Cost System was issued to AEC and department management for the months of July and August. This report is scheduled fox issuance on a quarterly basis beginning with September and ending with Nay. The report schedule was established to provide ample time to dispose of ITY 1065 variances from standard prior to closing of the books at June $30,1.65$.

Inventory of Precious ivetals and Special Materials vas talian at the end of Seprember.

Special requests hindided in september included the shipment of I $\mathrm{kg}$ of plutonium metal to 3attelle, a plutonium oxide-shipperreceive: study, the burial of 204 drums of contaninated material for the University of California, and the processing of 6026 grams of plutorium scrap from HL (Project Whitney).

\section{Business Programs}

An estimate of $\mathrm{P}-210$ separations cost was prepared for inclusion in the over-all APC PO-2IC production study. Separations operating cost wes estimaced at $\$ 1,600,000$ aniullily based on the giver reactco pridution quatitics. Separations cost is the majoi operating cost fastor in this program.

The vaste managenert supriement, detailing vaste manasement costs included in the ge Rerired leactor Cost studies, was issued in Septembe:.

The CPD Data Bock tias rerisea and undeted to include FY 1964 cost and activities. 


\section{General Accounting}

As of August 3I, 1964, vinetieer active projects had incunred costs of $\$ 3,208,922$ agtinst autinvized furis of $\$ 6,026,424$. Outistariding commitrnents totalea $\$ 533,+47$.

There were eicht appropulation requests approwed during septemiler, 1964 authorizing expenditures of:

$A R$

No.

Descripticn

Section Amourit

56012 X-ray Flourescent Spectrometer

56013 Plutonium Product Conceritreator.

56014 Solids Moisture Analyzer

56015 Surface Area Analyzer

56016 Electric Motion

56017 Arc Spark Stand

56018 Temperature Recorders

56019 Infrared Spectrometer

Purex \$25 030

Purex 3C.000

WMO

7250

WIMO

9500

Purex 2000

WMiO

3200

R\&EO 8500

R\&EO

7600

TotaI

$\$ 93080$

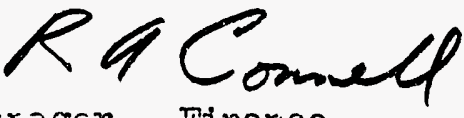

Marager - Finarice 
CHEMICAL PROCESSING DEPARTMENT

MONIELY REPORT

SEPTTEMBEER 1964

II. ACHIEVEMENIS (continued)

\section{F. FACIIITIES ENGINEERING OPERATION}

1. Purex

a. Process Design Ringeering

Multipurpose Dissolver Inserts

The study drawings of the first three insert concepts were issued for preliminary review. Nine alternate proposals for stavewall construction are being reviewed by the nuclear safety consultants for feasibility. Neutron absorption tests are to begin shortly upon four alloys. Corrosion studies are in progress.

Dissolver Tower

Fabrication of the Purex Dissolver Tower and Knockout Pot is proceeding according to schedule and will be ready for tube installation as soon as the finned tubes are received on-site.

Purex Processing Flexibility

\section{Part 1}

Design Review - Fifty-one (51) drawings were reviewed this month. A revision to the design criteria has been sent to the Atomic Energy Commission f'or approval. This revision will permit usage of $\mathrm{TK}-11$ in the Purex 211-A Tank Farm, a 100,000 gallon acid storage tank, for storage of $\mathrm{NH}_{4} \mathrm{NO}_{3}$ solution, and thus obviate the need for a new tank. 
Purex Processing Flexibility (continued)

$\underline{\text { Part } 2}$

Engineering Study

The engineering study for Part 2 has been completed and issued for distribution.

Variable Jet Feed Control

Engineering work was started during the past month on a control system for a variable jet in the Purex

3WF Stream. The jet will transfer solution from Tank F-10 to E-H4 concentrator. Engineering of the system is now approximately 40 percent complete, and arafing is scheduled to start within the next few days. It. is presently anticipated that fabrication work wipl be started by the end-of October.

Re-design of Canyon Coaxial Connectors

Re-design of original in-canyon coaxial connectors has corrected all disadvantages. Also, use of commercial parts and standardizing of all holes to standard drill sizes has reduced cost of fabrication to $1 / 3$ of former costs. ( $\$ 1,450$ for one (1) complete set of connectors for one (I) head to $\$ 450$.

b. Project Engineering

CGC-124 - Increased Processing Flexibility - Purex

Eighty-seven (87) drawings have been issued for comment; thirty-six (36) have been approved. Fabrication of moderators was started on September 9.

\section{c. Manufacturing Engineering}

\section{Laboratory Dry Waste Handling System}

Canning equipment to package Purex Laboratory dry wastes was received and installed for testing. Initial testing of the integrity of the can seal has been confined to simulated wastes. A study is now in progress to determine the best

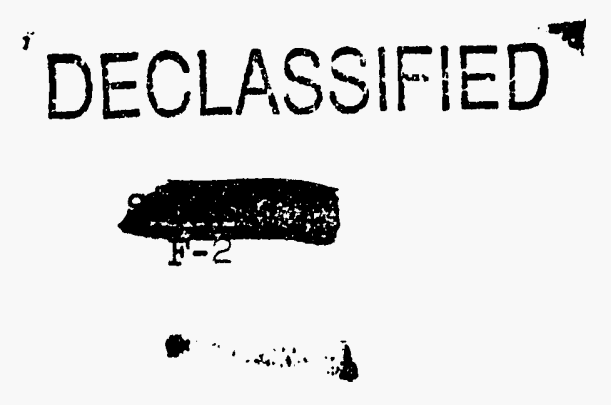


location of equipment control switches so that laboratorles may receive a mintmum amount of radiation during the packaging operation.

241-A Tank Farm Sluilce Pump

Failure of the 125 horsepower pump motor on the sluice pump in the 102 Tank. was caused by the steam atmosphere in the pump pit. Since only an open-type motor could be used on the existing pump, a replacement motor has been installed. This motor has been equipped with a shroud and furnished with air Iram outside the pump pit. The exhaust air is also collected and exhausted through a filter to outside the pump pit.

2. $\underline{\operatorname{Redox}}$

a. Process Design Engineering

Dissolver Off-gas $I^{131}$ Monitor

The new Redox off-gas I $I^{131}$ Monitor was put into service during the past month. The system is operating satisfactorily with one exception; the system sensitivity is too great. Although at the present time Redox is processing material that is quite old (should have very low Il31 content) the monitoring system is counting about $5 \times 10^{4}$ counts per minute. This means that when Redox again starts processing relatively "green" feed, the count rate will be beyond the range of the instrument. As a result, steps are presently being taken to reduce the crystal size in the detector and also possibly to collimate the garma beam.

In-Iine pH Probe - Redox Stream

The In-line pH probe on the Redox IAS stream is still inoperative. Failure was attributed to the reference electrode which was designed with an upper limit of $122^{\circ}$ F。 Temperature of the process stream has increased recently from less than $100^{\circ} \mathrm{F}$ to approximately $180^{\circ} \mathrm{F}$. Temporary substitute electrodes were recommended for Redox and investlgations have been started to obtain better electrodes for this application.

b. Project Engineering

None.

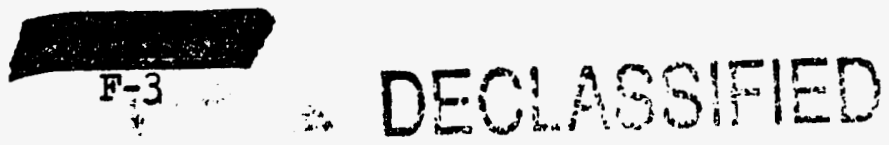




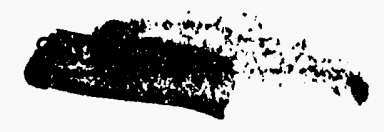

HW- 84354

c. Manufacturing Engineering

Redox D-14 Tube Bundle Insert.

A replacement coil for the Redox D-14 Tube Bundle is being fabricated or: an emergency basis by the Chemical Processing Department Shops. It is scheduled for installation on Octiober 5 .

\section{Weapons Manufacturing}

a. Processing Design Engineering

"C" Buttor Lire

Two (2) replacement fluorinator bellows were received, a nd one (1) is being prepared for installation in HC-9B for evaluation. Equipment for removing $\mathrm{P}_{\mathrm{Li}} \mathrm{O}_{2}$ in $\mathrm{HC}-9 \mathrm{~B}$ has been fabricated and installed. Testing of the jaw-tiype crusher has proceeded satisfactorily with rocks as the material to be ground. The jaw cmisher is interided as replacement for the hammermill in the HC-17DC, and is to be housed in a new hood.

\section{"A" Button Line}

Ten (10) drawings have been revised in preparation for the renovation of H-9A (fluorinator and salciner). Engineering was completed for installing vacuum systems on the 4 th and 5 th stations of the Ingoting Glove Box. Fabrication and installation have started for the 4 th station.

\section{Plutonium Reclamation}

The TK-06 slag and crucible dissolver is now back in service after replacement of a tapered stainless steel spool piece with a teflon-lined spool piece and replacement of a teflonlined tee in which the lining had bulged to prevent feed can passage.

\section{Incineratior}

Fabrication and installation of a two-unit inlet filter assembly to provide rentilation air from the room to the cyclone ash separator glove box has been completed. This installation precludes the need to supply ventilation air to this glove box from the ash canning glove box and allows the vent between them to be blanked, thus preventing dust passage from the canning section to the cyclone section through the vent. Engineering on removable insulation for the incinerator beit pulliy housing has been

\footnotetext{
Ya.

DECLASSIFIED
} 
completed. A nuclear safety review of the design is presently being made.

Plutonium Residue Suryey Within "Z" Plant

A two-week period was devoted to survey of selected equipment within the " $\mathrm{"}$ " Plant using $380 \mathrm{KEV}$ gamma emission from Pid239 to detect any quantities of plutonium residues. The survey was limited to the $9 A$ and $9 B$ ventilation system within the duct level and to the incinerator building. A comprehensive report covering the results of this survey is being prepared. Preliminary results indicate no problems of criticality.

b. Project Engineering

CAC-987 - Stabiization Facility - 234-5 Building

Design was completed on September 8 . All vendor drawings have been recelved and approved.

CAC-138, Rev. No. 1 - Special Plutonium Preparation Facility - Z-Plant

A project proposal revision, reducing the scope of work by one glove box and some minor equipment was transmitted to RLOO-AEC on September 21. The removed features are currently being provided by AR-46039 for processing Euratom material.

4. General

a. Processing Design Engineering

Waste Management Program

Design data and material establishing all the in-concrete piping and electrical services in Cell 15 - "B" Plant for the CGC-132 prototype equipment were completed and transmitted for continuation of detail design. This information fulfills scheduled requirements for this phase, except for control room and jumper criterla which are to he supplied April 1, 1965.

The design criteria document for Phase III WAFRAX was officially issued by the Atomic Energy Commission to Vitro for start of detail design. The design criterla document for Purex Shielded Analytical Laboratory was approved by RLCO-AEC.

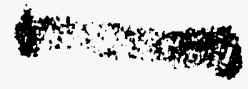


FPCE Plant (Fissior Produst Conjersior and Ercapsulation)

All phases of this stuiy requested last month by the Commission are proseedirg on sahedule. All drawings have been issued for comment and are scieduled for firal reproduction during the first week of ortober. Tha document portion of the study is scheduled for completior iz we foiswing week.

\section{b. Projest Engineering}

Project cost Information (as of $9 / 13 / 64$ )

Total Authorized Funds - 19 astive projects

Total Coet-to-date

Commitments and Open Work Releases

Unencumbered Beisace

Costis Charged to we above projests

$(8-23-64$ to $9-13-64)$

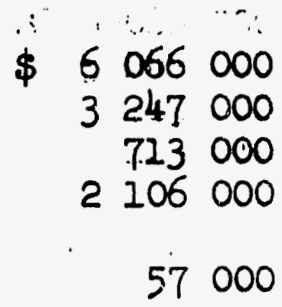

CAC-144 - Waste Fraotior zation - "B" Plant

Directive No. AEC-244, dated Septembsy 25. Suthorized $\$ 10$, , 00 for initiatior o: desiza.

5. Shops

Craft and equipment services were furnished the operating facilities as required, to assist ir meeting processing schedules. In addition to accomplishments included with processing plant reports, the following completions were made in Shops work: 21 jumpers were fabricated, tested, and deifivered io processing bulldings; the Purex F-6 Demister was advarced to the 277-W Bullding mock-up cell for further work: the 24-C Machining Hood was re-located to the "A" Lire iri 234-5 Buildine: the HAPO I-B-I Cask was loaded for off-site shipment and seyeral plastic panels were fabricated for the 234-5 Building.

\section{Power and Services}

Steam and electrical semices were provided without intermption to assure continuity of operation of production facilities. Renovation of the purex high tank has been completed and the tank restored to normai semice. This completes the high tank renovation program for CPD. Painting was completed on al1 200-East and West general area steam trarsmissicr ines, and trap stations were upgraded.
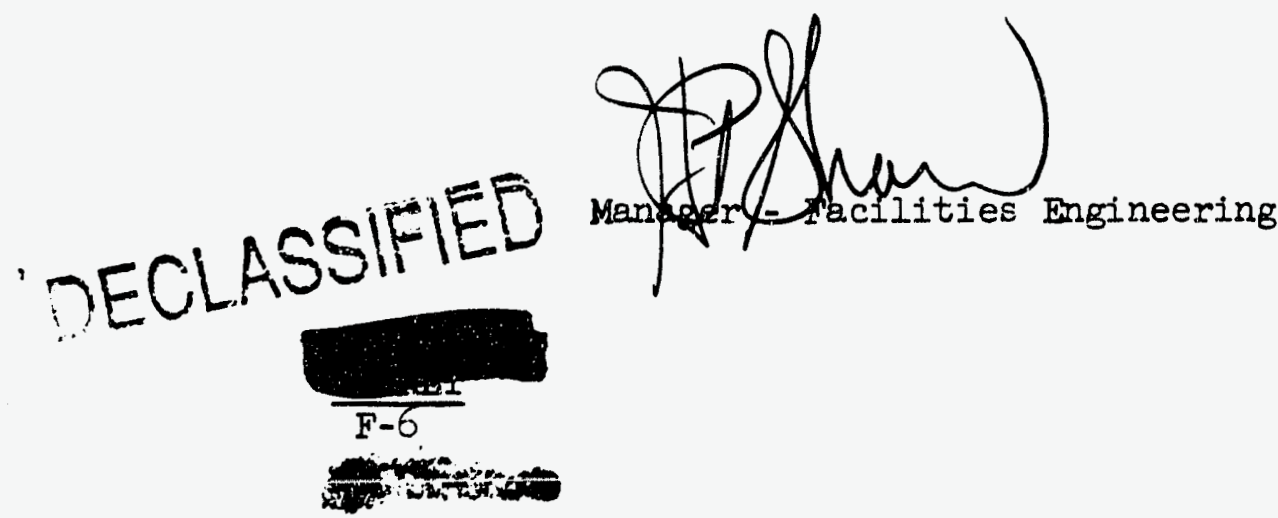
CHEMICAL PROCESSING DEPARTMENT

MONTHLY REPORT

SEPTEMBER, 1964

II. ACHIEVEMENTS (Continued)

G. RESEARCH AND ENGINEERING OPERAT ION

\section{Purex Process Engineering}

a. Critical Mass Control

Critical mass control in the Purex Plant has been augmented by the recent installation of two prototype systems. A plutonium neu tron monitor has been installed on the HAF make-up tank, which receives plutonium rework, and the plutonium ion exchange backcycle line equipped with continuous plutonium gamma monitors. The new systems, in conjunction with the prototype IBXP neutron monitor, provides prompt in-line evidence of plutonium movement within the plant, especially noticeable during periods of high exposure plutonium processing or extensive plutonium rework.

b. Solvent Extraction

Process water quality has been monitored by uranium transfer rate measurements for over a year. Permanganate treatment of the water at the filter plant has been shown to be effective in removing organic material and maintaining water quality for stable operation of the uranium stripping columns. Recent laboratory studies indicate passing water through a bed of activated charcoal or adding charcoal to the alum water treatment step may be superior to permanganate treatment.

c. Uranium Product

The Purex uranium product zirconium-niobium specification for normal enrichment uranium was approximately doubled on a test basis to take advantage of the existing uranium oxide storage policy. The new specification will minimize the need for silica gel processing and will reduce the amounts of uranium that must be reworked. Long term use of the new specification is dependent on maintaining low radiation exposure levels in the uranium calcination plant.

\section{d. Canyon Ventilatjon Filter}

The differential pressure across the Purex Plant ventilation filter continues to oscillate with the trend indicating an increase in differential pressure. The differential pressure has been observed to increase from approximately six inches W.g. to as high as thirteen inches in an hou.

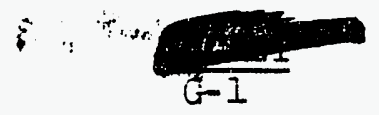




\section{DECLASSFIED}

HW- 84354

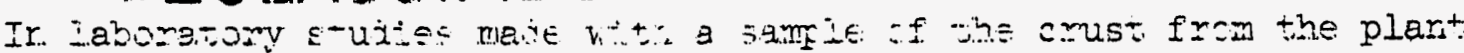

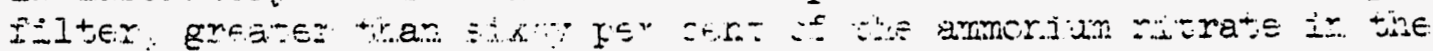

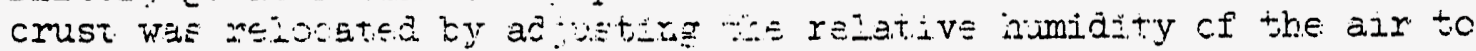
ez.ghty-fzve Ifer cont for rive of four dejy.

\section{Redox Prcoezs Ergensen...ng}

\section{a. Acid Defisiens Precrate Ficiseses}

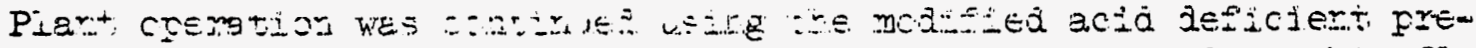

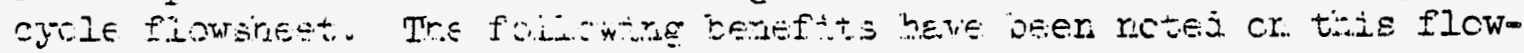
stseet:

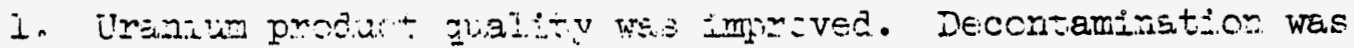

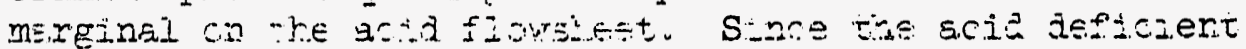

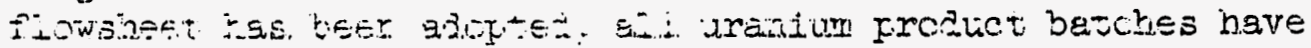
$b \in \therefore r$ we

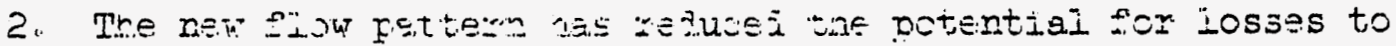

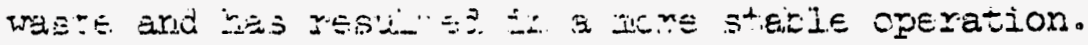

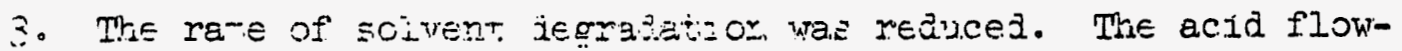

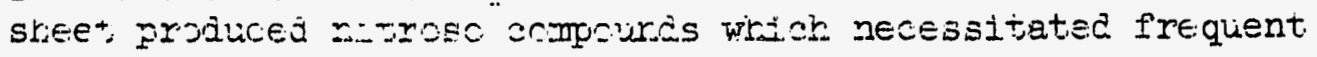
crgaric washos.

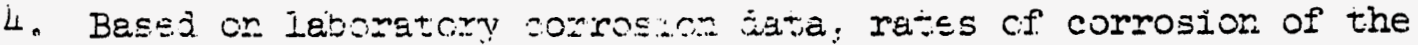

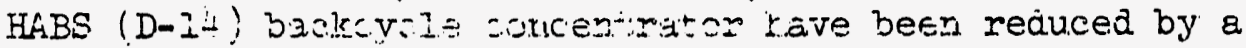
facton of ebcit: fis.

\section{b. HA Columr. Performance}

Ir order to reduce tre potential for ficoding out the bcttom of the columr, the new HA Columr was mojifise ky introducing the organiz intc an enlarged coricai section just above the packing surpcrt grating and

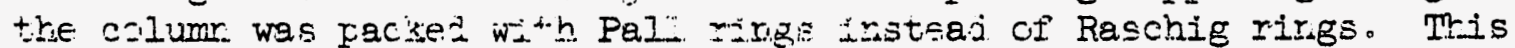
column was instailed in sidg is: The new 20 ume tas operated i8 consecutive days at an 8 to fer jiy rete kfore ar acid filish was required. The best performance trat lad been doristred witn the cld HA Columr was 15 days cf continuouz operation st a 5 tor per day rate.

\section{Plutonium Prosess Engireerirs}

\section{a. Rer:orery}

Three changes were maje in tife protctype slag and crucibie thermo-sypion dissolver after the initial pluggage reported earlier for the month of July and Auglist. A perforated tibe was instalied above the heating leg screen to fermit tire therma: anclieticr to contine in spite of large amounss of solids. A coarse sereen was substztuted for the fire screen in the heating leg, and a fire screer was unstalied in the lower cross piece. Thirty (30) cans had beer charged to the dissclver following the changes when the first newiy recomerided $4 \mathrm{M} \mathrm{HNO}_{3}$ flush was performed on the dissciver. Twerty (20) more cans has beèn charged when the second $4 \mathrm{M} \mathrm{HNO}_{3}$ flush was required. However, slower reaction rates following

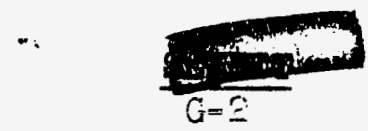


these charges indicated that the cans were not getting down into the dissolver as they should. The top cross piece " $T$ " was removed, and the teflon liner was found in a bulged condition that prevented the charged cans from dropping all the way down into the dissolver. Thts bulged condition is believed to be due to overheating which occurred with the inftial pluggage. The offending "T" wes replaced and dissolving resumed. The reaction rates returned to the earlier experienced levels but quickly dropped off. Instrumentation irdicated pluggage again after only 15 cans had been charged. After the $4 \mathrm{M} \mathrm{HNO}_{3}$ flush, pluggage again occurred after only 4 cans had been charged. The bottom piece was removed and found to be plugged with solids upstream of the fine screen. This fine screen, which had a low free area has now been removed. Approximately 5 liters of solids were removed from the cross piece, and the plutonium content was estimated at less than 50 grams. Dissolving has not yet been resumed.

The prototype in-line plutonium monitor originally installed on the aqueous raffinate (CAW) stream was found unworkabie on the CAW stream and has been moved to the stripped organic (CCW) stream. The monitor has worked quite well in the two weeks it has been in use on the CCW siream. The instrument is based on measuring an X-ray which is characteristic of plutonium.

The first americium has been removed from the Phase I (americium isolation, partial purification, and concentration) of the Americium Recovery Facility. Approximately 7.6 grams were removed on September 25, 1964, in 18 liters of solution. This amount has accumulated since start-up on August 6, 1964 . However, not all available feed material from the Plutonium Reclamation Facility was processed through the Americium Recovery Facility due to early hydraulic difficulties between facilities and limited capacity of the flowsheet. The plutonium concentration in the recovered americium solution was less than $0.01 \mathrm{~g} / 1$.

b. Incinerator

Solids have been found in the incinerator off-gas scrubber solution since initial operation. The solids have all been black and carbonaceous in appearance and slow to settle out. However, some gray solids were discovered last month on the tank bottom and sampled this month. The plutonium content of the solids was 0.15 per cent by weight, and the total volume of solids was estimated at approximately two liters. So far, laboratory attempts at dissolution of the solids have been unsuccessful.

\section{Separations Chemistry Laboratory}

a. Purex Process Improvement

Water Quality Studies

Additional tests were completed in an effort to define more closely the relationship between water quality and Purex extraction performance. Assuming that the uranium transfer rate (UTR) with distilled water to be optimum (100 per cent), other water samples were tested to determine the effectiveness of crarcoal treatment (150 ppm) as foliows:

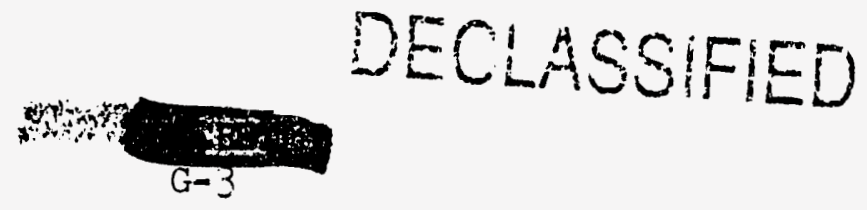




\section{DEC FIED}

HW- 84354

$\begin{array}{lr}\text { Raw Water } & 65 \text { per cent } \\ \text { Clear-Well Water* } & 75 \text { per cent } \\ \text { Raw water + Charcoal } & 89 \text { per cent } \\ \text { Clear-well water + } & \\ \quad \text { Charcoal } & 98 \text { per cent } \\ \text { Distilled water } & 100 \text { per cent }\end{array}$

* Raw water $+\mathrm{KMnO}_{4}+\mathrm{Alum}+$ filtration

Infrared analyses of the charcoal extract were non-enlightening. Studies on water quality and de-ionizing methods are continuing.

b. Redox Process Improvement

Ceric Ion as Process Oxidant

Neptunium decontamination from fission products is most effectively carried out in an acid deficient cycle. However, the dichromate oxidation used to form the extractable neptunium +6 is not effective in an acid deficient system. Armonium hexanitrato cerate was evaluated in the laboratory and found to be an excellent oxidant for neptunium in an acid deficient system even at ambient temperatures. This compound is very soluble in water and will permit the processing of neptunium through the Redox extraction columns on an acid deficient flowsheet during neptunium campaigns.

c. Miscellaneous Products Improvement

The "cold" run which started in August using yttrium as a stand-in for promethium was completed during the month. Essentially all of the yttrium was recovered at 98 per cent purity. The major metallic impurity was iron which amounted to 1.6 per cent. Total operating time for the "cold" mun was 372 hours. Examination of the analyses of the column effluent streams indicates that operating time can be reduced to 30 to 40 hours per run by routing only the promethium band plus a portion of the preceding and trailing band to subsequent columns.

Piping changes have been made within the I-F cubicle to allow regeneration of a column or columns while eluting other columns, thus allowing more efficient use of the equipment. The silicone mubber gaskets between the columns and the column jackets are being replaced by rubber gaskets. The lead brick shielding is being installed in front of the valve rack. It is anticipated the "hot" run will start in October.

\section{Americium Purification}

Development work in Hanford Laboratories, which demonstrated the possibility of purifying americium in the same type chromatographic process as used for promethium, led to the decision to utilize the laboratory equipment in 222-S for demonstration of an americium purification process. Activities which will permit utilization of the chromatographic equipment for both promethium and americium purification have been started.

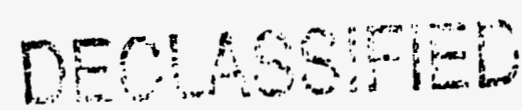

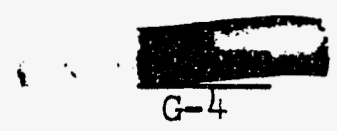


d. Laboratory Imprcyemen:

\section{Chromatographic Method fCr TBP-DBBP}

A gas chromatcgraphic metrod was de eicpoz frer TBP and DBBP in carbon tetraw chloride. Separation was made or $z 4^{\prime} \times$ I/G" I.D. column of Apiezor "N" heated to $150 \mathrm{C}$. Under these corjiticns, TBP acmes off the column two minutes after the DBBP begine elutinn $T<e$ peiks mist be quantitatively resolved by subtraltirg the DBBP contribu-let to the TBP peak using the area under the dibutyl methy- prcsphcnate psak as refsrense. Concentrations of TBP and DBBP can be quantitativejy mezsured dcwn to 0.5 voiume per cent while 0.2 volume per cent of either ccmpian can be $z \in t e c+e d$.

\section{Atomic Absorption Develcpment:}

Aditional work with shck voastructed helicw brass eatrcdes has satisfactorily demonstrated the feasibility of using trese eqtrode saurces in place of the more expensive glass-erclosed catrodes aved lih is on the open market. Lcrer levels of letection in lig/mi $x$ cold syntherie samples have been demonstrated on impurities of interest as feilows:

$\mathrm{Ni}-0.05, \mathrm{Fe}-0.05 . \mathrm{C}-0.02 \mathrm{z}-0.02$ Fr -0.20 , c. .0 .01 , Ga -0.05 , $\mathrm{Mg}-0.01, \mathrm{Na}-0.005, \mathrm{Ag}=0.02$

The flame area has been enclcsed in a hood for contaminaticr control and evaluation of performance on hct samfles will be started in October.

\section{Silicon Metal Analyses}

The search for improred methodi cf anaivsis for siizizor sortinued zuring the month. Experience with th coivrimeric moiybdate method has been ids" couraging because of non-repreducible resuits.

The $\mathrm{X}$-ray fluorezence unit was tried for silicon detection laing a chromium target tube and an ammonium dirydrcgen frcaphate gxatzng with promising resilts. After extraction of the flutcrium. a detection limit of 10 ig cf $S$. was realized on the sample melint. This metrci appsars to be promising and will be further developel.

\section{Thermogravimetric Develcrmenta}

The vertical tube trermobalance unit hal beer in routine use evaluating tre reactivities of $\mathrm{PuO}_{2}$ pohders from $\mathrm{Z}$ Plir." Corjideration is beirg given to

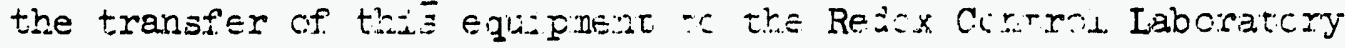

A small $1000^{\circ}$ tube furrace has been purchased and it is being set up in a gloved box. This furnace will be equipped to perferm Fyrchydrolysis stidies on fluorides as weli as exygen to metal ratics on $1: t a i$ oxiles or on Pli-ll mixed oxides for tre Z Fiart jeve Lorment program

The uranium calciner and trermibalance has beer revised and will be placed back in service. Apprcximately a month's wcrk remains before the calcinaticn reactivity studies sar. be scmeieted satisfactcrily.

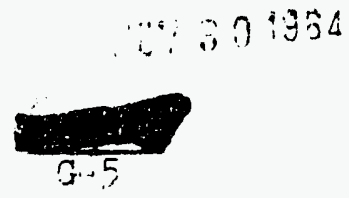




\section{DEUHSSIFIED}

HW- 84354

Multi-Charnel Analyzer Deveierment

The Multimcomponent Aralytical Program (MAP) has been programmed on the 7090 computer. Analvijeal resuits of gamma energy standards wiIl be submitted to this program for statistical analysis starting witr the standards isslied for tre fcurth calendar quarter of 1964. The program is available for strer applicstcons. A letter has been written to advise of this change and of the avalability of the program.

Redox Anaivticai Lasonatory has Eireazy started to resord the results of the daily anaivs is of the "Response and Reccrery" standard lised to characterize the performance of the differ $n^{+}$. ccmbinations of detectors and puise hejght analyzers. Sufficiert dita cards were submitted tc provide a basis for statisticai analysis and the results will be tabulated with the third quarter standards repcrt.

Irradiated iron and titanium folls were sent to Geei, Belgium, as part of an intercalibraticn excharge of tinreshold monitor, activation product analysis by means of gammz energy analysis between HAPO and Euratcm. A similan exeharge with coirat and nickel soils has been completea witi exceilent resuits

\section{Plutonium Chemistry Laboratory.}

a. CGC-912-W2 Column Problems

The difficulties experienced in stripping of the cclumn with Nonr.u and neutralizing the carsonate solution have been examined by simulating plant operation in iabcratory batch tests. The lack of good material balance over the reacidification step has been attributed to the presence of an organic substance which is removed from the $\mathrm{W}-2$ column organic phase due to its solubility in carbonate solution. This material then separates from the aqueous phase upon treatment with acid. This organic substance floats on the surface of the aqueous sciution and extracts plutonium. Although this organic material constitutes considerably less than cne per cent of the total solution, it extracts about. $1 / 3$ of the plutonium by virtue of its rigk distribution coefficient [EQ(Pu) 103].

Although the organic substance has not been identified, it is ressonable to suspect it tc be DBP, a degradation product of TBP, which has an appreciable sclubility in water.

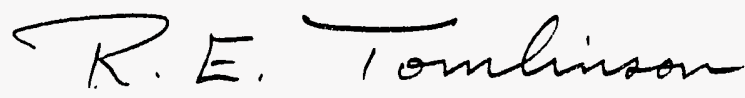

Manager

Research and Engineering

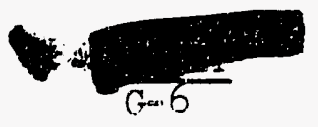


liquid to slurry zone so rapidly that the liquid-slurry region is very short, thus producing a slurry buildup. It was this concluded that the maximum feed concentration permitted by the calciner is $300-350 \mathrm{~g} / \mathrm{I}$.

A new 3000 watt Calrod unit was installed in the 18" furnace of the calciner. The existing 12" furnace was moved to the product end of the calciner and the new 18" unit placed at the feed-inlet end. The change will allow a greater heat flux to be maintained in the slurry zone of the calciner. It is now possible to increase the feed rate and lower the product volatility content.

b. Fluorination Reactivity Tests

Batch fluorination tests have established a SO4/Pu ratio of 0.25 as the optimum additive ratio for maximum oxide fluorination. Tests were made on oxides having $\mathrm{SO} 4 / \mathrm{Pu}$ ratios of $0,0.15,0.25$, and 0.5 . The reactivity of the direct-calcined oxide varied from 70 to 100 per cent of that observed with line oxide. The percentage of the oxide fluorinated varied from 40 to 80 per cent as determined by analysis.

c. Ion Exchange Resin Hazards

Several samples of Dowex 1 ion exchange resin were received from the vendor and were converted to the nitrate form.

The heats of combustion as a function of cross-linkage were measured in the Parr Bomb calorimeter. The results are tabulated below:

\begin{tabular}{|c|c|}
\hline & esin \\
\hline Dowex & $\begin{array}{l}1-X 1 \\
1-X 2 \\
1-X 4 \\
1-X 8 \\
1-X 10\end{array}$ \\
\hline
\end{tabular}

$$
\frac{\text { Heat of Combusion (Calories/Gram Dry Resin)* }}{\text { Wet Drained Resin }}
$$

$\begin{array}{cc}\text { Would not ignite } & 6,450 \\ 6,950 & 6,750 \\ 7,350 & 7,100 \\ 10,700 & 7,360 \\ 9,125 & 7,180\end{array}$

(*) Average of at least two combustions.

At the present time it is difficult to account for the differences between the heats of combustion of the wet, drained resin and the same resin after it has been dried. Work will be continued to try and explain these discrepancies.

In earlier work it was found that Dcwex I resin had about the same spontaneous ignition temperature as Permutit SK. When the newly received Dowex resins were tested, however, it was found that the nitrate form of the resin after being washed with water did not ignite at temperatures up to $230^{\prime} \mathrm{C}$. The Permutit SK under similar treatment, on the other hand, ignites at about $200 \mathrm{C}$. The Dowex resin will now be tested after nitric acid washing to see if acidwashed resin also has a higher igniticn than the Permutit acid-washed resin.

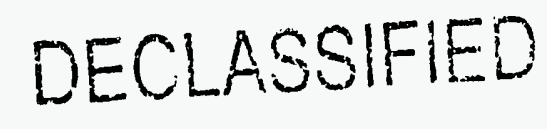


d. Electrorefini:ng Ceil:

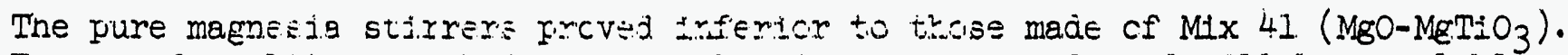

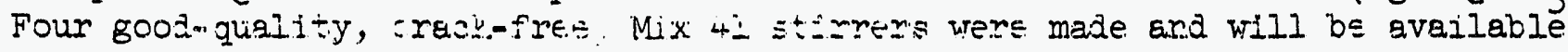

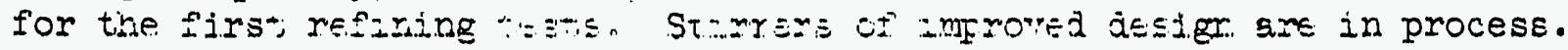

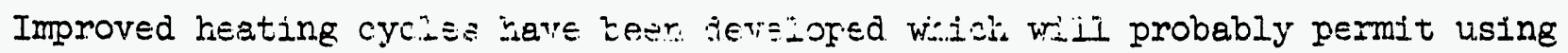
the ceIls alresiy prediuej. Hovever, $\quad$. $r$. celis writhout cracking trem; heree a tromie:e, bevalled: non-ceme:ted cell

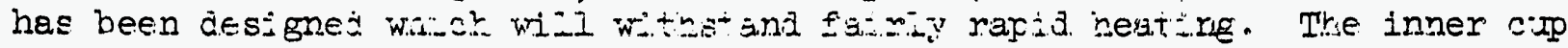
wili be centered ky fitting troto tie teven of the cuter cmicibie, and will be

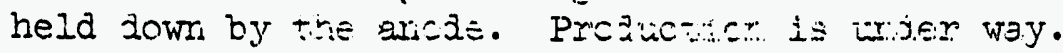

e. Fission Product, Recovery

Recovery of sged pronethium from tre sisferded jilage in TKo IOS A continued during the mortr. Prometrium- 43 to prometizim-147 ratics confirmed the average age of TK-IOG-A $i=$ in excess ö thic years. Even thougt. cleanouts were made to mirimi ze ex ass-anctaminatior: of agsd promethium with green

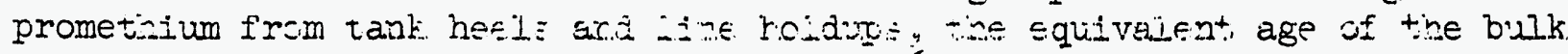
of the recoverea promstium was $r=a$ uced $c$ c 500 days. The first 150 kilocuries was ccrtaminated to ar equi "alent age of 450 ajy.

f. Technetium Recovery

A second technetium recovery campigr. ina werigken in conjunction with a cesium loadout for Oak Ridge. Trs sfar STT aask containing about 50 cubic feet of strong base anion resir. WEa aguis openatej in series with the cesium casks. After lcaling, the resir bed was itsishez with four column volumes of $1.0 \mathrm{M}$ sodium nydroxide, $1.5 \mathrm{ajumr}$ volumes of $0.25 \mathrm{M}$ nitric acid, and eluted with seven cilum viumes of $6 \mathrm{M}$ nitric acia. During the elution, the nitric acid was continiolisly corcentrateil and aestroyed with sigar in a concentrator.

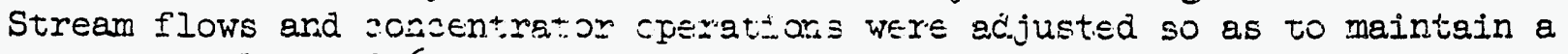
constart volume cf $6 \mathrm{M}$ ritr:c anij in the scncentrator during the denitration. A sugar efficiency of 40 meils of a:ja destrovej per moie ci sugar was measured with sixty per cent of the destroyed soid afpesring in the condensate after passage through a single sorderiser.

\section{g. Thorium Proce इing}

Preparations for the six ton thor.um proosss test ir Purex are well along in terms of flowsheet definition and test.r. pro product form specifications and handling, analytical metrods jevel-pinert, anj defirition of zaryon routing

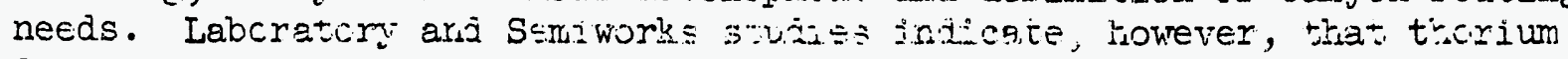
dissolution in a nonrecircilsting zystem is very sioh. Means for improving dissolution of the six ton test material ir the existing pot aissolver are under review.

Manager

Researsk and Engineering 


\section{CHEMICAL PROCESSING DEPARTMENT \\ MONTHLY REPORT \\ SEPIEMBER, 1964}

III. PERSONNEL ACTIVITIES

A. FORCE SUMMARY

\section{Operation}

General Manager's Group

Financial

Fimployee Relations

Research \& Englneering

Fac1lities Englneering

Production

Redox

Purex

Weapons Manufacturing

Total

\section{Monthly Salarled Weekly Selarled $8-30-64$ 2-27-64 8-30-64 9-27-64}

Total

$8-30-64 \quad 9-27-64$

\begin{tabular}{|c|c|c|c|c|c|}
\hline Group & 9 & 9 & 1 & 1 & 10 \\
\hline Financial & 16 & 16 & 28 & 28 & 44 \\
\hline Employee Relations & 3 & 4 & 1 & 1 & 4 \\
\hline Research \& Engineering & 68 & 65 & 27 & 28 & 95 \\
\hline Fac1lities Englneerling & 100 & 97 & 324 & 207 & 314 \\
\hline Production & 6 & 5 & 3 & 3 & 9 \\
\hline Redox & 60 & 62 & 224 & 223 & 284 \\
\hline Purex & $T 2$ & 70 & 271 & 263 & 343 \\
\hline Weapons Manufa cturing & 62 & 60 & 267 & 263 & 329 \\
\hline Total & 396 & 388 & 1036 & 1017 & 1432 \\
\hline
\end{tabular}

B. PERSONNET CEANGES

P. H. Reinker, General Manager - Chemlcal Processing Department, transferred to Fuel Recovery Study Operat1on, APED, effective September 1, 1964.

Effect1ve September 1, 1964, J. H. Warren transferred from Manager Production, to General Manager - Chemlcal Processing Department.

Effective September 1, 1964, H. B. Lindkerg transferred from Relations and Occupational Health Operation to the position Specialist - Communications and Community Relations.

W. S. Frank, Manager - Research Englneer1ng, transferred to Electronics Component Division as General Manager - Electronics Specialist Capacitor Products Section, Irmo, S.Co, effect1re September 14, 1964. 
C. TRIPS

Visitor

To Other GE Components

M. H. Curtis

J. H. Werren

H. P. Shaw

M. D. Alford

E. M. Johnston

\section{DECLASSIFIED}

To

Netixe of Discussior.

\author{
Vallecitos \\ Pleasanton, Calif. \\ New York, N.Y. \\ Pleasactcia, Calif. \\ King of Prussia, \\ Penna.
}

Dissuss mixed oxide teshnology。 (9/9/54)

Manufacturing and Engineerling Services. $(9 / 15,16 / 64)$

Fission produets. $(9 / 24,25 / 64)$

Packaging seminar. $(9 / 29,32 / 64)$

To AEC and Other AEC Contractors

H. T. Fullam

A. E. Smith

I. I. MeGregor
Oak Ridge Natioral Lab. Oak Ridge, Tennessee

Argonne National Lab. Lemont; III.

Mounds Laboratory

Miamisburg, Obio

Bendix Corp.

Kazsas CAty, Missourt
Solgel process.

(9/15/64)

Fluoride volatility. High temperature reactor fuels. $(9 / 16,17 / 64)$

Plasma chemistry Oxide teshrolozy. (9/18/64)

Attend IMOG Steering Combittee mettirg. $(9 / 2 \varepsilon, \geqslant 3 / 64)$

To General Industry

H. D. Haberman

To Conventions and General Meetings

Pacific
Seattle
Meetings

G. C. Oberg

M. D. Alford
Las Vegas, Nevada
Attent 5tth National Meeting of Americen Institute of Chemical Engineering. (9/21-23/64) Station Equipmert. $(9 / 22,23 / 64)$ 


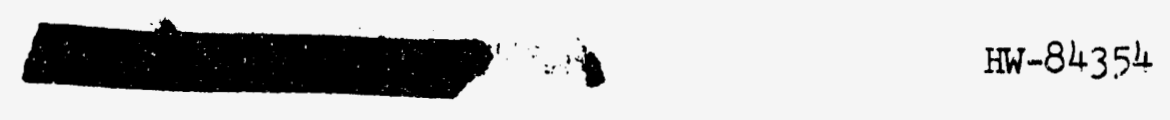

D. VISITORS

Visitor From Nature of Discussion

From Other GE Components

P. C. Bisonette Idaho Falls, Ida. Fissior Products。

$(9 / 29 / 64)$

From AEC and Other AEC Contractors

W. A. Morrill

J. D. Yates

T. M. Yakimchick

J. D. Moseley

From General Industry

M. F. Ohman

I. B. Venable

H. D. Doan, President

A. P. Beutel, Vice Pres.

W. J. Rave

M. F. Ohman

I. B. Venable

W. K. MacCready, Consultart

C. R. Maul

J. W. Dickinson

J. E. McCune

J. W. Uhler

F. M. Cochran

J. V. Pearson

S. Davis
Bureau of Budget, Washington, D.C.

Division of Military Applieation,

AEC Division of Production

Dow Chemical Co. Rocky Flats Plant Denver, Colorado

Dow Chemical Co. Midland, Michigan

Dow Chemizal Co. Midland, Michigan

$\begin{array}{ll}\text { " } & \text { " } \\ 1 " & \end{array}$

Stearns-Rogers, Derver, Colorado

Linde Co. Seattle, Wash.

HUICO, Pasco, Wash.

Liviversty Indlistrial do.

United Nuclear White Plains, N.Y.
Tour of Purex, B Canyon, SSW and Waste Facilities. $(9 / 9 / 64)$

11

11

Plutonium nitrate shipperreceiver demonstration.

$(9 / 21-25 / 64)$

Plant tour of Purex and

B Plant. (9/3/64)

Tour of Purex and $B$

Plant. (9/11/64)

Fabrication of Pulse

Generators. (9/18/64)

Weldirz Equipment In-

stallation. $(9 / 21 / 64)$

Weldire Equipmert. (9/23/64).

Fission Product Processes.

$(9 / 28-29 / 64)$

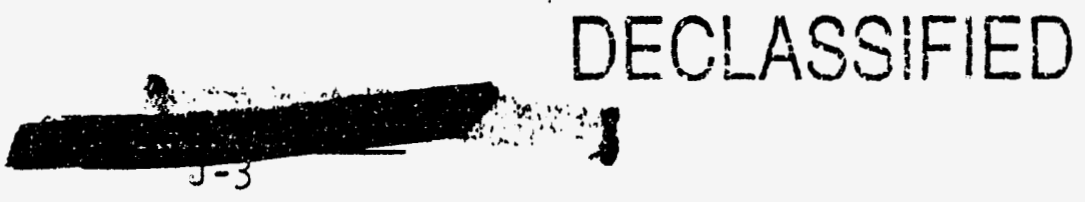


D. VISITORS (Continued)

\section{DECLASSIFIED}

\section{Visitor}

From General Industry (Continued)
A. J. Cassell
Monsarto Chemisal so. Daytor:, Ohio
P. Crutchfield
Martir-Marietta co. Baltimore, Mö.

Nature of Dissussion:

Fissior. Product Processes. $(9 / 28,29 / 64)$

Purex and Fission Produsts. $(9 / 29 / 64)$

From Other Government and Forelgn Agencles

J. Klitgaard

Eurochemic

Mol, Belgium

Separations processing, fissior produet, waste management programs.

$(9 / 22-24 / 64)$ 


\section{CIIE IICAL PIOCESSIIIG DEPARTI EITT}

I:OITTHLY REPORT

SEITE:BER, 1264

IV. SAFETY AND SECURITY

\begin{tabular}{|c|c|c|c|c|c|c|c|c|c|}
\hline Operation & Purex & ino & FEO & Redox & Roe & Finance & Prod. & $\begin{array}{l}\text { Empl. } \\
\text { Rel. }\end{array}$ & Total \\
\hline Dis. Injiries & & & & & & & & & 0 \\
\hline Ser. Accidents & & & & & & & & & 0 \\
\hline lied. Treat. Inj. & 13 & 7 & 11 & 4 & & & & 1 & 36 \\
\hline Rad. Occurrences & 2 & 4 & & 6 & & & & & 12 \\
\hline Contan. VIds. & & & & 2 & & & & & 2 \\
\hline ITew Deposition Cases & & *2 & & & & & & & 2 \\
\hline res & & & & $* * 1$ & & & & & 1 \\
\hline ecurity Violations & 1 & 1 & & & 1 & & & & 3 \\
\hline
\end{tabular}

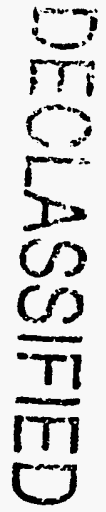

* Both caused in inhalation occurring 6-22-6!, lid i.PBS or less.

* Fire 64-10, Septeriver 10 . A: ash tra was exptiec into a vaste container with a plastic liner, icnitine waste paper. 
V. REPORTS

\section{A. PREPARED AND ISSUED}

HW-69730 REV, Unclassified, "Critical Mass Control Specification - Storage of Plutonium in Room 172, 234-5 Building", dated september 14, 1964, by R. J. Sloat.

HW-81242, Secret AWD, "Button Specifications", dated March 9, 1964, by R. E. Van der Cook.

HW-82294 L7, Secret, "Button Purity Data - Letter No. 7", dated September 3, 1964, by R. J. Sloat.

HW-822.4 I8, Secret, "Button Purity Data - Ietter No. 8", dated Septtember 17, 1964, by R. J. Sloat.

EW-83600, Unclassified, "Design Criteria - Purex Analytical Laboratory Additions", dated August 3, 1964, by L. R. Michels.

$\mathrm{HW}-83636$, Secret, "200 East Area Water Study", dated Aligust 11, 1964 , by J.W. Barnes.

3W-83735, Secret AWD, "Proposal: Direct Ingoting of Unpickled Buttons for Economic and Prodict Quality Gains", dated September 2l, 1.964 , by R. H. Bnnd.

HW-83736, Secret AWD, "Preparation of Delta-Stabilized Plutonium by Direct Alloy Blend Techriques", dated September 2l, 1964, by R. H. Bond.

HW-83772, Official Use Only, "Project Proposal, Rev. No. I - Special Plutonium Preparation Facility - Z Plant (Project CAC-128)", dated September 11, 1964, by C. A. Lyneis.

HW-83774, Secret AWD, "Plutonium Ignitior", dated August 26, 1964, by A. E. Smith.

HW-83802, Secret AWD, "Addition to FPT 64-25 - Alternate Feed Preparation Methods", dated August 26, 1964, by S. T. Field.

HW-83897, Secret AWD, "Fabrication Process Test - FPT-64-34 - Polishing of 74-C Parts with Nylon Scouring Pad", dated September 2, 1964, by A. E. Barber. 


\section{DECLASSIFIED:}

HW-84354

HW-83908, Secret AWD, "Weapons Process Finineelng Technology Report - August, 1964", dated September 3, 1964, compiled by members of the weapons

Process Engineering Operation, Research and Engineering.

HW-83911, Unclassified, "Critical Mass Control Specification - Removal of Plutonium from Hoods 9-A and 9-B", dated September 18, 1964, by R. J. Sloat.

HW-83912, Unclassified, "Critical Mass Control Specificatior - Storage of Plutonium Compounds - Operatior Gallery, 22.4-T Building", dated September 17, 1964, by R. J. Sloat.

HW-83919, Secret AWD, "Abstracts of Contributions for JOWOG 22 Meeting October 6-8, 1964", dated September 2, 1964, by A. E. Smith.

HW-83975, Secret, "Plutonium Concentration and Storage, Engineering Study for Purex "L" Cell Package Replacement", dated September 8, 1964, by C. W. Smith.

HW-83976, Confidential, "Plutonium Scrap From NUMEC", dated September 8, 1964, by M. K. Harmon.

HW-83998, Unclassified, "U-233 Reduction - Study Flow Sheet", dated September 15 , 1964 , by M. H. Curtis.

HW-84023, Unclassified, "Engineering Study, Purex Sludge Removal and Waste Transfer - 200-E Area", dated March 18, 1964, by E. Doud and L. W. Roddy.

HW-84040, Unclassified, "Recomended Changes to the 234-5 Building Analytical Laboratory Ventilation System", dated August 20, 1964, by M. E. Borgeson.

HW-84107, Secret, "Review of Proposed Flowsheet and Routings for the Improved Neptunium Accumulation Flowsheet - Redox", dated September 15, 1964 , by L. R. Michels.

HW-84139, Secret, "The Use of Chemical Additives to Improve First Cycle Decontamijation at Purex", dated September 25, 1964, by T. R. McKenzie.

HW-84148, Jnclassified, "Critical Mass Control Specification - Plutonium Oxide Shipper-Receiver Demonstration", dated September 21, 1964, by R. J. Sloat.

HW-84161, Secret AWD, "Proposed Process Test to Evaluate Direct Ingoting of Unpickled Buttons", dated September 2l, 1964, by R. H. Bond.

HW-84162, Secret AWD, "Proposed Proness Test to Evaluate Effectiveness of Reduction Vessel Purging", dated september 2l, 1964, by R. H. Bond.

HW-84165, Secret AWD, "A Iine Product Characteristiss - August 1964", dated September 18, 1964, by A. E. Smith.

HW-84197, Unclassified, "Isotopic Exchange Samples 7641 and 7642 ", dated September 23, 1964, by O. F. Beaulieu.

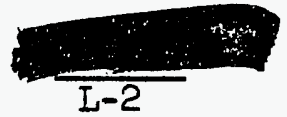




\section{otasented}

HW-84206, Unclassified, "Invecrion Report: Dire:t Ingoting of Unpiokled Plutonium Metal Buttons", dated September 2l, 1964, by R. H. Bond.

HW-84249, Secret AWD, "Evaluation Report - FPT-64-7 - Test of Co-Reduced Alloy in the Fabrication of Model 74-C Components", dated September 23, 1964, by S. T. Field.

HW-84282, Confidential, "Oferating Plans for Redox - October - Scheduled Shutdown - Purex", dated septeminer 28, 1964, by M. K. Harmon

HW-84292, Unclassified, "Analyses of PIutonium Samples (XXXIV - 1 to 5) on Interplant Exchange Program", dated September 29, 1964, by 0.F. Beaulieu.

HW_SA-3536, Unclassified, "A Quantitative Separation for Magnesium, Calcium, and Strontium Using Zirconium Molybdate Ion Exchange Crystals", dated September 24, 1964, by M. H. Campell.

B. PREPARED FOR SIGNATTRE AND ISSUANCE

HW-84022, Secret, "Production - August, 1964" dated September 11, 1964, by W. E. Johnson. 


\section{An \\ DECLASSIFIED}

HW-84354

CHEMICAL PROCESS.ING DEPARTMENT

MONTHLY REPORT

SEPTEMBER 1964

\section{PATENT SUMMARY}

All persons engaged in work tikat might reasonably be expected to result in inventions or dissovenies advise that, to the best of their knowledge and belief, ro inventions or discoveries were made in the course of their work during the period covered by this report, except as listed below. Such persons further advise that, for the period therein covered by this repnrt, notebook records, if any, kept in the course of their.r work have been examined for possible inventiors or disooveries.

INVENTOR

Rudolph Dejong, Fauillties Eirginee:ixg

Edward F. Stell, Facilities Exineerang

R. H. Bond, Research \& Engireering

\section{TITLE}

A Prosess Solution Control System Froviding Criticality Safegrards in Nurlear Vessels and To Accurately Regulate Solution Transfer Flow Rates Between Related Nuclear Prozessing Equipment.

Sampling of Bulk Solids in uranular and Pordered Form.

Direot Ingoting of Inpickled Flizonium Metal Bittons.

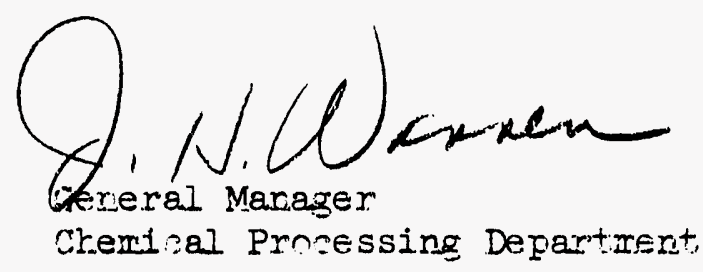

Sweith 

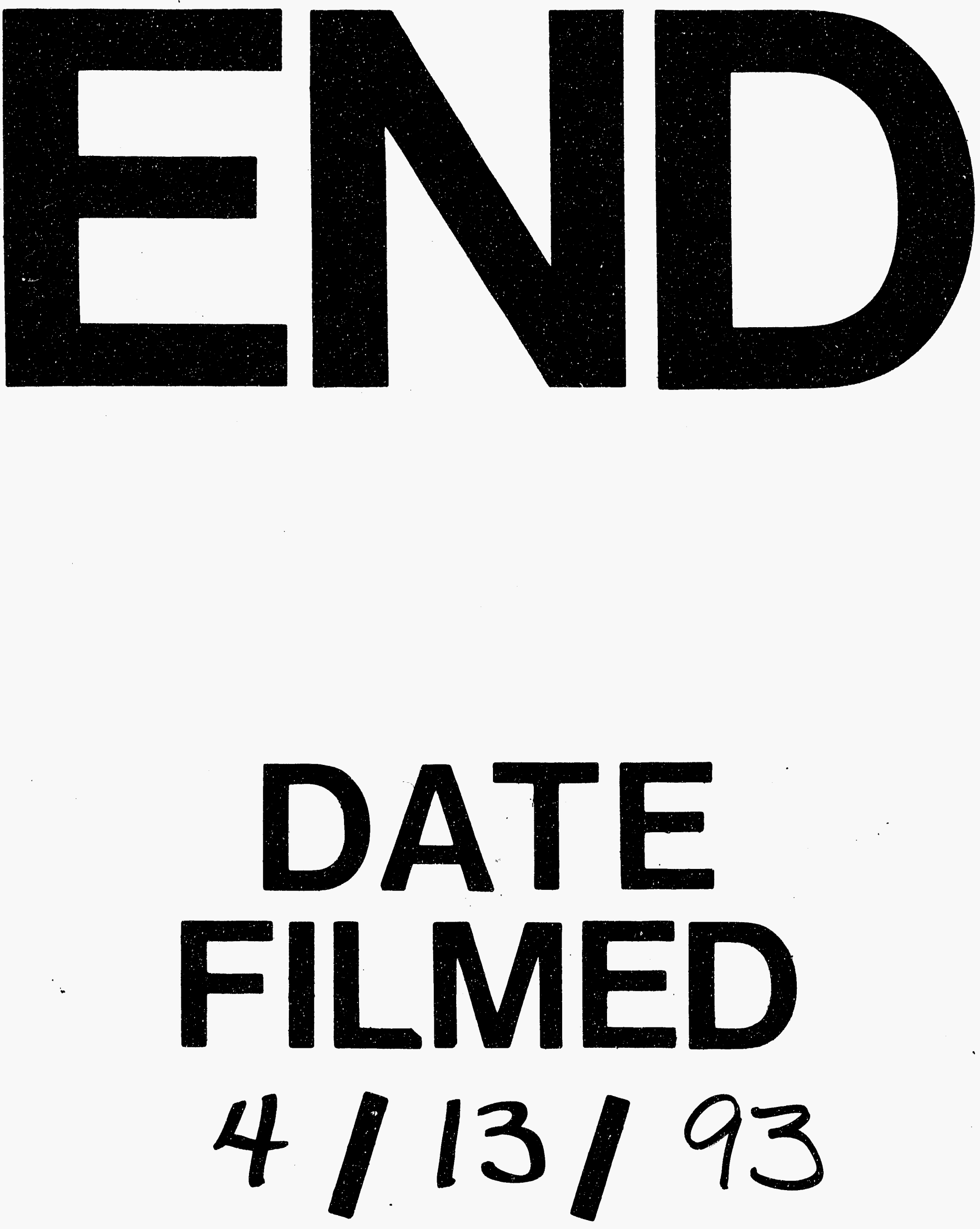

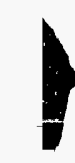


